\title{
Correction to: Efficiency of bioaerosol samplers: a comparison study
}

\author{
Esra Mescioglu (1) • Adina Paytan • Bailey W. Mitchell • Dale W. Griffin
}

Published online: 11 August 2021

This is a U.S. Government work and not under copyright protection in the US; foreign copyright protection may apply 2021

\section{Correction to: Aerobiologia https://doi.org/10.1007/s10453-020-09686-0}

Due to a production problem the article "Efficiency of bioaerosol samplers: a comparison study", written by "Esra Mescioglu, Adina Paytan, Bailey W. Mitchell and Dale W. Griffin", was originally published electronically on the publisher's internet portal on 19 March 2021 without open access.

The article has been changed to Open Choice. The copyright of the article has been changed to (C) This is a U.S. Government work and not under copyright protection in the US; foreign copyright protection may apply 2021 and the article is forthwith distributed

The original article can be found online at https:// doi.org/10.1007/s10453-020-09686-0.

\section{E. Mescioglu $(\square)$}

Earth and Planetary Sciences, University of California, Santa Cruz, CA, USA

e-mail: Emesciog@ucsc.edu

\author{
A. Paytan \\ Institute of Marine Science, University of California, \\ Santa Cruz, CA, USA \\ B. W. Mitchell \\ College of Engineering, University of Georgia, Athens, \\ GA, USA \\ D. W. Griffin \\ U.S. Geological Survey, St. Petersburg, \\ FL, USA
}

under the terms of the Creative Commons Attribution 4.0 International License, which permits use, sharing, adaptation, distribution and reproduction in any medium or format, as long as you give appropriate credit to the original author(s) and the source, provide a link to the Creative Commons licence, and indicate if changes were made. The images or other third party material in this article is/are included in the article's Creative Commons licence, unless indicated otherwise in a credit line to the material. If material is not included in the article's Creative Commons licence and your intended use is not permitted by statutory regulation or exceeds the permitted use, you will need to obtain permission directly from the copyright holder. To view a copy of this licence, visit http:// creativecommons.org/licenses/by/4.0.

The original article has been corrected.

Open Access This article is licensed under a Creative Commons Attribution 4.0 International License, which permits use, sharing, adaptation, distribution and reproduction in any medium or format, as long as you give appropriate credit to the original author(s) and the source, provide a link to the Creative Commons licence, and indicate if changes were made. The images or other third party material in this article are included in the article's Creative Commons licence, unless indicated otherwise in a credit line to the material. If material is not included in the article's Creative Commons licence and your intended use is not permitted by statutory regulation or exceeds the permitted use, you will need to obtain permission directly from the copyright holder. To view a copy of this licence, visit https://creativecommons.org/licenses/by/4.0/. 